\title{
“Los límites del honor". Nobles y jerarquías de Brasil, Nueva España y Perú, siglos XVII y XVIII
}

\author{
Ronald RAMINELLI \\ Universidade Federal Fluminense (Brasil) \\ rraminelli@uol.com.br
}

Recepción: 17 de enero de 2014 / Revisión: 17 de marzo de 2014

Aceptación: 5 de mayo de 2014 / Publicación: diciembre de 2014

\section{RESUMEN}

Este artículo se orienta al estudio comparativo de las noblezas de América (Brasil, Perú y Nueva España) entre los siglos XVII y XVIII. Las estrategias de ascensión social y las intervenciones políticas de los nobles en las milicias y en los cargos municipales, son temas centrales en esta investigación. Los nobles titulados, caballeros e hidalgos vivían en Perú y Nueva España. En Brasil actuaban solamente los fidalgos y caballeros que no siempre tenían las calidades de un noble. Los episodios aquí reunidos vienen a demostrar que las noblezas americanas tenían privilegios muy debilitados y constantemente señalados como amenazas al orden colonial.

Palabras clave: Brasil, Perú, Nueva España, nobleza, privilegios, calidades, siglos XVII y XVIII.

\section{"Los límites del honor". Nobility and Hierarchies in Brazil, New Spain and Peru, $17^{\text {th }}$ and $18^{\text {th }}$ centuries}

\begin{abstract}
This article aims toward a comparative study of the American nobilities (Brazil, Peru and New Spain) between the $17^{\text {th }}$ and $18^{\text {th }}$ centuries. The central themes of this research are the nobles' strategies for upward social mobility and their political involvement in the militia and municipal offices. Titled nobles, knights and "hidalgos" lived in Peru and New Spain. In Brazil, noble presence was limited to "fidalgos" and knights that didn't necessarily possess noble qualities. The incidents discussed here show that the American nobilities possessed considerably weak privileges that were constantly seen as threats to the colonial order.
\end{abstract}

Keywords: Brazil, Peru, New Spain, nobility, privileges, qualities, $17^{\text {th }}$ and $18^{\text {th }}$ centuries.

Sumario: 1. Introducción. 2. Definiciones de nobleza. 3. Títulos ultramarinos. 4. Indios y mulatos en las órdenes militares. 5. Privilegios de nobles y ciudadanos. 6. Conclusiones. 7. Referencias bibliográficas. 


\section{INTRODUCCIÓN ${ }^{1}$}

En enero de 1726, los oficiales de la câmara (cabildo) de Río de Janeiro escribieron al soberano para denunciar la presencia de falsos nobles en la ciudad. Acostumbraban venir a esta ciudad "muchos vagabundos y hombres de poca consideración" que para obtener ventajas recurrían a los símbolos de la nobleza. Contra los servicios de Dios, del rey y del bien común, ellos simulaban tener honores y así engañaban a los pobladores que los reconocían como hombres de bien, como personas de buena fe. Eran las apariencias, o quizás fuesen las insignias, las que incentivaban el buen recibimiento de los impostores, a los que se les facilitaba la concreción de negocios. Las personas del lugar eran engañadas y perjudicadas. Más allá de este daño, los "vagabundos" querían violar la circunspección de las cosas de las cuales son indignos. Para evitar los embustes, los hombres de la câmara solicitaban al soberano que todas las personas que pasasen por la Capitanía de Río de Janeiro fueran obligadas a registrar en el senado de la câmara los honores concedidos por la monarquía. Más allá de certificar la veracidad de los hábitos, de los fueros y de los escudos de armas, los oficiales pedían que aquellos que simulaban ser nobles fueran multados 200.000 reis, una suma que en parte era entregada al senado de la câmara. La no presentación de estos documentos, "era entendido como una falsedad" y, por lo tanto, los forasteros eran entregados a la justicia para ser procesados por esta violación ${ }^{2}$.

En principio, la carta de los oficiales de la câmara nos remite a los vínculos entre lealtad y nobleza, entre honor y buenos negocios. Basados en las insignias nobles, los pobladores de las ciudades confiaban en los forasteros y realizaban negocios con ellos, aunque eran perjudicados con su falsa identidad. Para evitar engaños, la câmara de Río de Janeiro buscaba tener conocimiento y registro de las mercedes, una prueba cabal de la existencia de los oficios y privilegios recibidos. En la monarquía portuguesa, cabía a las câmaras preservar la memoria administrativa de las localidades; de hecho, los ediles actuaban como policía y justicia en primera instancia, ya fuera por el control del comercio o del aparato urbano. Las peticiones al monarca indican, sin embargo, que la práctica de registrar las honras no era frecuente en Río de Janeiro. Dado que la carta de los oficiales no tuvo continuidad, el Consejo Ultramarino no vio necesidad de que la câmara controlase a los nobles radicados en la capitanía ${ }^{3}$.

Aun cuando no se tenga otras informaciones sobre el interés de la câmara por registrar las honras, cohibir, multar o arrestar a los "nobles impostores", el episodio nos remite a cuáles eran los temas de mayor importancia para el ultramar luso-brasilero. Vale la pena enumerarlos, pues los documentos demuestran no solamente los límites entre los nobles y el vulgo en ultramar, sino que sobre todo muestran la diferencia entre la "nobleza de la tierra" y la nobleza respaldada por la monarquía, es decir, por-

\footnotetext{
1 Agradezco la ayuda y sugerencias de Roberta Stumpf, Revista Complutense de Historia de América, Rafael Chambouleyron, Fernanda Bicalho, Erika Dias y Thiago Krause.

2 Carta dos oficiais da Câmara do Rio [de Janeiro], ao rei [D. João V]. Rio de Janeiro, 08-VII-1726. Arquivo Histórico Ultramarino de Lisboa [en adelante AHU]. Rio de Janeiro, avulsos, doc. 1861.

3 En los cabildos de la América hispánica tampoco existían registros sobre la diferencia entre nobles y plebeyos (pecheros). Esta información, en general, era indispensable para los municipios de España, pues allí se viabilizaba el cobro de impuestos personales, véase BüsCHGES, 1996, p. 169.
} 
tadora de papeles semejantes a los solicitados por los oficiales municipales de Río de Janeiro, como fue indicado anteriormente. Es más, los hombres de bien de la câmara formaban parte de la nobleza, llevados a esta condición cuando recibieron los mismos privilegios de la câmara de Oporto, honra también concedida por la monarquía a los ciudadanos de varios municipios luso-brasileros.

Los ediles tenían muchas razones para controlar a los forasteros que llegaban a la ciudad. Cabe entonces mencionar el intenso y desordenado crecimiento de la ciudad de Río en medio de los descubrimientos de oro en Minas Gerais y el aumento del comercio. La urbe, como punto de llegada de las personas provenientes del reino y también de ultramar, se convirtió en un espacio de gran movimiento de personas $\mathrm{y}$ movilidad social ${ }^{4}$. Ciertamente, tales transformaciones promovieron un ambiente apropiado para la aparición de falsos nobles.

Además, en América, las diferencias entre los fidalgos/hidalgos y los plebeyos portugueses tendieron a nivelarse, pues el mar de indígenas transformaba a los colonizadores en gentilhombres ${ }^{5}$. La esclavitud de los indios, de los negros y la creciente población mestiza potenciaron el ideal ibérico que concebía el ocio como la primera condición para identificar a los nobles. Más allá del origen judío y moro, el color de la piel era determinante para distinguir a los nobles del vulgo en ultramar, aunque a veces este obstáculo era relativizado. De todas formas, así fuesen portugueses, nacidos en Brasil, jefes indígenas, negros o mulatos, las estrategias para transformarse en noble diferían poco cuando éstos se presentaban como leales vasallos que servían al soberano y por tanto suplicaban una merced. Como parte de la estrategia de ennoblecimiento en los años setecientos, los militares y comerciantes fueron incitados a comprar tanto el perdón real por sus oficios mecánicos, como los papeles que comprobasen servicios militares, así como también los propios títulos de caballeros de las Órdenes Militares. Aun cuando la venalidad lo alteró, el ideal de nobleza se modificó poco durante el período colonial.

Para investigar las noblezas y su honor, no emplearé muchas fuentes primarias, sino una bibliografía muy diversa. Con tema tan amplio no sería viable recurrir a los archivos europeos y americanos. Además, la comparación a veces presenta limitaciones. Las definiciones de hidalguía y fidalguia tenían puntos comunes, pero no eran iguales. Los súbditos de Nueva España y Perú tuvieron un acceso relativamente fácil a los títulos nobiliarios, mientras que en Brasil estos honores eran casi inexistentes. Muchos militares indígenas y mestizos ingresaron en las Órdenes Militares portuguesas en el siglo XVII, lo que era excepcional en España. Por fin, para completar el panorama de las noblezas americanas y los límites de su honor, este artículo investiga los privilegios de la nobleza, sobre todo los concedidos a las principales cámaras de Brasil, tema relevante en los estudios del municipio colonial. En principio, los cabildantes hispano-americanos no recibieron el mismo honor. En este caso particular, no se puede comparar, pero tal restricción no llega a imposibilitar la investigación.

\footnotetext{
4 Bicalho, 2003, pp. 199-227.

5 Schwartz, 1988, p. 212; Raminelli, 2013.
} 


\section{DEFINICIONES DE NOBLEZA}

En Castilla, entre los siglos XVI y XVIII, se encontraban entre los nobles tres grupos jurídicos y sociales: los hidalgos (de sangre o de privilegio), los caballeros (hidalgos urbanos enriquecidos) y aquellos nobles que recibieron los títulos ${ }^{6}$. Según Villasboas y Sampayo, la nobleza más conocida y respetada en España era identificada por la sangre, "heredada de los antepasados con informaciones de su origen". Contrarrestando, "nuestros Portugueses como siempre averiguan los datos de la nobleza más con la espada que con la pluma...". Adelante en su narrativa, en vez de describir al fidalgo en general, debido a la complejidad de la jerarquía, Sampayo disertó sobre los fidalgos del solar y los fidalgos de los libros del Rey. Del primero, mencionó el origen de la casa y la notoriedad de su nobleza; del segundo, se valió de los antiguos caballeros, escuderos y los registros en el Libro de la Casa Real. Aunque en el tratado Nobiliarchia Portuguesa (1676) los fidalgos allí se destacasen por los servicios militares, las referencias a la sangre y linaje eran recurrentes ${ }^{7}$.

En el Tratado de nobleza (1591), frey Benito Guardiola mencionó el linaje al enumerar las peculiaridades de los hidalgos: la nobleza proveniente del padre, abuelo y bisabuelo. Es decir, el honor y las virtudes heredadas por línea paterna. Sin embargo, si el hidalgo se uniera a una persona de más bajo nivel, su hijo sería hijo dalgo, pero no noble. Es más, si una hija dalgo tuviera un hijo con alguien de más bajo nivel, el vástago no tendría "por bien ni por derecho que fuese contado por hijo dalgo" ". Entre las primeras calidades exigidas por los caballeros de la Orden castellana de Santiago estaba "ser hidalgo de sangre de padre y de madre y no de privilegio". Así, a los hijos de padre hidalgo y de madre plebeya, o de condición inferior, no les estaba asegurada la calidad suficiente para ingresar en las Órdenes Militares y se les exigía la limpieza de la sangre materna, pues la "herencia matrilineal podían transmitirse también dignidades y títulos"

La fidalguia puede ser analizada no solamente por medio de los tratados de nobleza, sino también por la política real de remuneración de los servicios. Reconozco que los casos de indígenas y mestizos de Brasil que recibieron hábitos de caballeros constituyen excepciones en la extensa lista de caballeros y fidalgos insertos en la nobleza a partir de sus hazañas. Para mejor analizar la idea de linaje en Portugal, vale la pena recurrir a las Matrículas dos Moradores da Casa Real ${ }^{10}$. Debido a esto, es preciso mencionar la compleja jerarquía entre los fidalgos. Había dos órdenes de fidalgos, siendo la primera superior a la segunda. En la primera, estaba el fidalgo cavaleiro, fidalgo escudeiro y moço fidalgo; en la segunda, el cavaleiro fidalgo, el escudeiro

6 Domínguez Ortiz, 1973, p. 56-57. Los hidalgos eran bastante menos representativos en América donde aún cuando proliferaban los caballeros de las Órdenes Militares, eran raros los hidalgos de privilegio. BÜSCHGES, 1996, pp. 173-175.

7 SAMPaYo, 1676, pp. 147-168.

8 Guardiola, 1591, pp. 61v-62 y 66.

9 Postigo Castellanos, 1988, p. 138; Guillén Berrendero, 2008, p. 168.

10 Estudio cuantitativo realizado a partir de la edición de Amaral, 2009. 
fidalgo y el moço de câmara. Así, el fidalgo cavaleiro era un título con más honor, mientras que el moço de câmara era menos prestigioso ${ }^{11}$.

En el período entre 1641 y 1681, 244 beneméritos recibieron el título (o fuero) de fidalgo. Junto a la concesión, se encuentran descritos de forma pormenorizada los tiempos y los lugares de los servicios. En general, los militares luchaban en el Estado de Brasil y Maranhão y a veces combatían también en el reino contra los españoles, contra los turcos en el Mediterráneo, en Flandes contra los protestantes, en India y Angola contra los holandeses y otros opositores. La descripción de las hazañas corroboran los vínculos entre las armas y la fidalguia, así como lo asevera Sampayo.

En relación a la filiación de los nuevos fidalgos, los documentos nos permiten concluir que eran raros (17\%) los beneméritos que eran hijos de fidalgos. Cuando se menciona la nobleza paterna, o mejor, el dato de que el padre era fidalgo, se percibe que el hijo recibió el mismo título. De esta forma, por ejemplo, el honor del padre raramente promovía la ascensión del hijo del segundo para el primer orden. Los fueros del segundo orden, particularmente los cavaleiros fidalgos, totalizan el $69 \%$ de todas las mercedes. Entre los fidalgos de primer orden, solamente 18\% eran hijos de fidalgos. Entre los 244 nuevos fidalgos, solamente $11 \%$ ya eran caballeros de las Órdenes de Cristo y Santiago. No obstante, entre éstos 27 caballeros con hábitos, 18 recibieron el fuero más prestigioso, el de fidalgo cavaleiro. En el cómputo general, no era la filiación noble un determinante para alcanzar el título de fidalgo cavaleiro, sino la relevancia de los servicios comprobados a la monarquía.

Para corroborar la noción de fidalgo en contraste con la de hidalgo, cabe mencionar que entre los 14 fidalgos de primer orden identifiqué tres mestizos. Los dos primeros eran João de Albuquerque de Mello (moço fidalgo - 1655) y João Soares Cavalcanti (fidalgo escudeiro y fidalgo cavaleiro - 1656) ${ }^{12}$, nieto e hijo del mestizo Jerônimo de Albuquerque Maranhão, y por lo tanto descendiente de Jerônimo de Albuquerque, el "Adán Pernambucano". El patriarca era portugués y se casó en 1547 con Tabira, india tabajara, después llamada María do Espírito Santo Arco Verde, y se convirtió en progenitor de un importante ramo de la aristocracia colonial. La familia estuvo íntimamente vinculada a la expansión portuguesa en dirección al este, a la conquista de Maranhão frente a los franceses y, posteriormente, a las victorias contra los holandeses en las guerras de Pernambuco y Maranhão.

El fidalgo cavaleiro Bento Maciel también era mestizo, hijo del portugués y gobernador de Maranhão de mismo nombre, Bento Maciel Parente, y de una india de São Paulo. Sobre el gobernador pesaba una mácula (el oficio mecánico de su padre), aunque fueron sus hazañas militares las que lo transformaron en caballero de la Orden de Cristo. Más allá de los servicios paternos, Bento Maciel (hijo) luchó contra los holandeses en Maranhão y contra los españoles, actuando como sargento-mor en Elvas. Al llevar a Belém las nuevas noticias de la liberación de la Capitanía de Maranhão del yugo holandés, el también caballero de la Orden de Santiago, Bento Maciel, fue capturado por los moros y llevado a Tetuán (Marruecos), donde padeció un

11 Guillén BerRendero, 2008, p. 286.

12 Livro de Matrículas dos Moradores da Casa Real. Lisboa, s.f. Arquivo Nacional da Torre do Tombo [en adelante ANTT]. Lisboa, liv. IV, fols. 53v e 172. 
cruel cautiverio. Fue preso durante casi 10 años y solamente fue liberado por medio del rescate de 8.000 pesos. Para ello, el Consejo Ultramarino puso a disposición la venta de sus propiedades en la Capitanía de Maranhão ${ }^{13}$. Al contrario de los mestizos -hijos de blancos con indias- cabe destacar que los beneméritos negros e indígenas no recibieron matrículas en la Casa Real, aun cuando esta dádiva real estuviera registrada en varios documentos y crónicas, sobre todo la concedida a Henrique Dias, militar negro.

El ennoblecimiento de la poderosa familia Albuquerque confirmó que su fidalguia se pautaba menos en la sangre y más en la determinación real. Sin embargo, cabe preguntarse si en el reino de Portugal las hazañas militares eran más importantes que el linaje para determinar la concesión del fuero de fidalgo; infelizmente faltan estudios sobre la nobleza portuguesa media y baja para responder a este planteamiento. De todas maneras, el poder del monarca para transformar al plebeyo en noble no siempre era bienvenido entre la alta fidalguia portuguesa. En sus escritos, Villasboas y Sampayo defiende que "la verdadera nobleza no puede dar el Príncipe por más amplio que sea su poder" ${ }^{14}$. Aún en Castilla, la noción de hidalguía también presentaba variaciones. En este sentido, cabe mencionar la tipología del conde duque de Olivares: hidalgos solariegos (los más antiguos y notorios), hidalgos notorios sin solar (destituidos del origen noble), e hidalgos de privilegio (concesión real de prestigio, comprado u adquirido por diversas vías) ${ }^{15}$. Se percibe en tales casos que hidalguía y fidalguia tenían significados muy parecidos, pero no iguales.

Siendo así, entiendo que la definición de Guardiola de nobleza puede explicar los motivos para no condecorar con hábitos a la nobleza de Tlaxcala (Nueva España), por ejemplo, que luchó por muchos años junto a los españoles. El énfasis castellano en el linaje, puede así explicar el atraso que existía en la remuneración de los descendientes de los incas y los mexicas. En las probanzas de Juan Melchor Carlos Inga, consagrado caballero de Santiago en 1627, los testimonios enumeran repetidas veces el origen virtuoso de sus ilustres parientes, su noble descendencia inca. A lo largo del extenso proceso, se mencionó particularmente el hábito de caballero de su padre, pero también las virtudes de sus antepasados que se remontaban a la del jefe supremo inca, Huayna Capaj ${ }^{16}$.

Además, entre 1640 y 1720, 296 americanos recibieron el título de caballero de la Orden de Santiago de España, pero 114 eran hijos o nietos de caballeros o de la baja nobleza; 87 eran descendentes de militares de alta patente (maestre de campo, coronel, capitán, capitán de infantería, gobernador y capitán general, alférez real, ...); 46 se originaban de familias que detentaban cargos importantes (oidor, consejero de S. M., secretario del Rey, secretario de cámara del virrey, gobernador, consultor del Santo Oficio, adelantado...) y 40 caballeros -incluso padres e abuelos- poseían sola-

13 Consulta do Conselho Ultramarino. Lisboa, 11-IX-1651. AHU. Maranhão, avulsos, doc. 296.

14 Sampayo, 1676, p. 29.

15 Guillén BerRendero, 2008, p. 279.

16 Pruebas para la concesión del Título de Caballero de la Orden de Santiago de Juan Melchor Carlos Inga, natural de Cuzco. Madrid, 1627. Archivo Histórico Nacional de Madrid [en adelante AHN]. OM Expedientillos, n. 1250 . 
mente el título de Don ${ }^{17}$. Por supuesto, la alta calidad de los caballeros estaba respaldada en la rígida noción de linaje castellano. A diferencia de las órdenes portuguesas, no hay registros de perdón regio para los beneméritos y familiares que detentaban trabajo vil u oficio mecánico.

En este sentido las diferentes aproximaciones de las dos monarquías sobre el tema nos permiten entender por qué la Corona portuguesa remuneró los servicios militares de los indígenas y mulatos sin averiguar la calidad de sus orígenes. Esta recompensa no estaba respaldada en el linaje noble, pero si en la valentía frente a las amenazas francesas y holandesas. A diferencia de los monarcas castellanos, la princesa Margarida tenía otra visión de los beneméritos, pues en defensa de los indígenas de Brasil aseveró que "los hábitos de las Órdenes Militares fueron establecidos desde su inicio para premiar a las personas que prestan sus servicios en la guerra..."18. En esa oportunidad, la gobernante no mencionó la importancia de la calidad para obtener las mercedes de hábito. Además, entre 1640 y 1720, la monarquía portuguesa condecoró con fueros de fidalgo y hábitos a muchos guerreros sin averiguar la calidad de sus orígenes. Los monarcas lusitanos prometieron muchas mercedes a hombres sin las calidades de un noble, o sea, a indígenas, mestizos, negros y a súbditos que trabajaran en los oficios mecánicos.

Vale todavía citar los estudios de Olival, Dutra y Krause que aseveraran la alta incidencia del perdón regio para los guerreros que habían tenido oficios mecánicos, o sea, que no detentaban linaje noble. Entre los caballeros de la Orden de Santiago la misma dádiva real benefició, entre 1667-1706, a 47\% de los pretendientes a un hábito, según un estudio de Francis Dutra. Entre los caballeros de la Orden de Cristo la cifra era inferior, pues el monarca perdonó solamente 18,9\% de los beneméritos, entre 1671 y 1680, como aseveró Fernanda Olival. En suma, entre Sampayo, la princesa Margarida y Guardiola, no creo que hubiese definiciones excluyentes de nobleza, pero si diferentes enfoques. Así, por más que los tratados portugueses determinaran la importancia de la sangre, la monarquía en la práctica gratificaba a los beneméritos sobre todo por sus servicios militares. Además, a mediados del siglo XVII, como aseveró Nuno G. Monteiro ${ }^{19}$, la monarquía portuguesa empezaba, a ampliar los estratos más bajos de la nobleza, recurriendo a las mercedes: los títulos de caballeros de las Órdenes Militares y los fueros de fidalgo. Por supuesto, la práctica de condecorar a beneméritos sin calidades era una estrategia de la monarquía para ampliar las alianzas en el ultramar, donde los hombres de calidad eran muy raros.

\section{TÍTULOS ULTRAMARINOS}

En el inicio de los setecientos, el jesuita André João Antonil afirmó que en las tierras de Brasil el prestigio y la honra de los señores de los ingenios diferían poco de la fidalguia del reino. Dueños de tierras, esclavos, edificios urbanos y rurales, los po-

17 Esta es una cuantificación de los datos ofrecidos por LoHMANN VILLENA, 1993, tomo 1.

18 Carta da Princesa Margarida. Lisboa, 26-XII-1635. ANTT. Lisboa, Mesa da Consciência e Ordens, Ordens Militares, Papéis Diversos, maço 20 n. 182. Véase también el documento n. 183.

19 Olival, 2001, 183; Krause, 2012, pp. 186-201; Monteiro, 1998. 
tentados también comandaban una vasta clientela, y a veces bandos armados, por eso eran denominados "principais da terra". En el mismo período, un procurador de la corona hizo comentarios poco favorables sobre los moradores de la América portuguesa, porque allí los hombres de posesiones, aunque de orígenes modestos, se daban aires de ser grandes fidalgos ${ }^{20}$. De hecho, eran solamente ínfulas fildalgas, es decir, los terratenientes actuaban en la sociedad como si fueran de la alta nobleza pero los papeles no les concedían tal distinción.

En la América hispánica los conquistadores y los hombres ricos podían efectivamente disponer de títulos de nobleza de Castilla, honor intangible a los súbitos ultramarinos del lado portugués del continente. Desde Carlos V, los monarcas concedieron, entre otros, los títulos de Marqués del Valle de Oaxaca a Hernán Cortés (1529) y el de Duque de Veragua y Marqués de Jamaica al hijo de Colón (1537). Más tarde, los reyes también condecoraron descendientes, que eran mestizos, de la antigua nobleza mexicana y peruana, así fue como doña Ana María Inga de Loyola (1614) recibió el título de Marquesa de Santiago de Oropesa. Ella era descendiente de los últimos incas de Perú. La monarquía universal concedió también los títulos de Vizconde de Ilucán y Conde de Moctezuma (1627) a don Pedro Tesifón de Moctezuma, bisnieto del emperador de Moctezuma II ${ }^{21}$.

Aun existiendo la concesión de los títulos de nobleza a los moradores de la América hispánica en los años seiscientos, los principales estudios se dedicaron a analizar el siglo de las luces. Vale la pena mencionar que al conceder los títulos máximos de la Corona de Castilla, los monarcas remuneraban tanto los servicios personales como la trayectoria de algunas familias. Más allá de comprobar los méritos y servicios, para obtenerlos, era necesario disponer de buenos procuradores y del apoyo de personas influyentes próximas al monarca. Para los habitantes de ultramar, la distancia era un obstáculo importante para recibir los honores. De cualquier manera, aún alejadas de Madrid, dos regiones se destacaron por la alta incidencia de los títulos nobiliarios. En los virreinatos de Perú y Nueva España, particularmente en Lima y la ciudad de México, se concentraba la mayor parte de los agraciados con los títulos de marqués y de conde. En el reinado de Felipe V, 318 personas recibieron títulos, de los cuales solamente 78 eran seguramente habitantes de las Indias de Castilla, pues 56 eran habitantes del Perú y 22 de Nueva España ${ }^{22}$.

Sin embargo, lo más notable, fue el peso de la venalidad en la adquisición de títulos, ya que, según Felices de la Fuente, solamente dos alcanzaron esta honra por sus méritos y servicios; los demás los recibieron por medio de la compra de títulos. A partir del último cuarto del siglo XVIII, se volvió evidente la disposición de la Corona de condecorar a los hombres más ricos. Por supuesto, la capacidad de reunir fortuna constituía un hecho y razón suficiente para convertirlos en nobles, mientras

20 Schwartz, 1988, p. 211.

21 Atienza, 1947, p. 15, 43, 44 y 71; Lira Montt, 1981, p. 634; 2010, p. 13-50.

22 No concuerdo con Rizo-Patrón cuando explica la concentración de nobles titulados en Perú: "Hemos adelantado alguna posible explicación para esta diferencia a favor del virreinato peruano, sobre todo frente al otro gran virreinato, el mexicano: la mayor lejanía del Perú desde la metrópolis peninsular, su vastedad y, por consiguiente, su gran complejidad administrativa". Rizo-Patrón, 2000, p.34. Basado en Kicza, creo que los peruanos tuvieron una concepción más tradicional de la nobleza comparada a los mexicanos; KICZA, 1982. 
que contribuyesen con la causa de la monarquía. Según D. A. Brading y Doris Ladd, en los años setecientos, la Corona otorgó aproximadamente 50 nuevos títulos a los residentes de Nueva España. Los comerciantes de origen peninsular y los propietarios de tierras criollos eran los principales beneficiados, seguidos por los mineros. Para el virreinato de Perú, no encontré números precisos. Lira Montt menciona un despacho real de 1675 en el que se comunicaba a los virreyes y cancilleres la concesión de 150 títulos a los americanos, a cambio de las siguientes sumas: el de vizconde valía 25.000 , el de conde 35.000 y el de marqués 45.000 pesos $^{23}$.

¿Sería entonces el título de nobleza una condición para posicionarse en la cima de la pirámide social en la América hispánica? En principio, Felices de la Fuente asegura la predominancia de los títulos nobiliarios, porque cree que todos los ricos más prominentes recibieron títulos ${ }^{24}$. Como señala Fredérique Langue, "los millonarios novohispanos eran nobles, pero que no todos los nobles eran millonarios". Sin embargo, para Kicza los títulos no actuaban como la principal distinción social, como tampoco eran sinónimos de patrimonio extenso e influencia social. A fines de los setecientos en la Nueva España solamente la mitad de las familias más ricas detentaban títulos de Castilla. Más allá de la honra mencionada, era la riqueza, el extenso y diversificado patrimonio, lo que distinguía a las "grandes familias", permitiendo su inserción en los puestos de prestigio en el gobierno civil y eclesiástico. Es decir, la compra y manutención de los títulos costaban bastante dinero y patrocinio a las familias y muchas no conseguían mantenerlos después de una generación. Aun así, en Zacatecas, según Langue, el espíritu empresarial y el status de la nobleza no se oponían, aunque se mezclaban, incentivados por la monarquía que condecoraba el éxito económico con privilegios y títulos. En suma, en Nueva España, el patrimonio diversificado y las ganancias de los emprendimientos eran más relevantes que los títulos, aunque los honores nobiliarios facilitaban la ocupación de puestos estratégicos en la burocracia, según $\mathrm{Kicza}^{25}$. Se percibe entonces una menor importancia de los títulos en México o tal vez un desinterés en gastar el patrimonio con la compra de títulos.

En la América portuguesa, la fidalguia con títulos se restringía a los gobernadores generales y particularmente a los virreyes, que permanecían por aquí solamente algunos años. Faltan estudios, pero considero que la nobleza de linaje tenía una participación muy reducida en la sociedad colonial. A diferencia de Portugal, la sangre no tenía la misma importancia en ultramar porque los hijos raras veces heredaban el fuero de hidalgo y los hábitos de caballeros de la Órdenes Militares obtenidos por sus padres. Así, los linajes no se mantenían, las familias por lo general perdían las mercedes concedidas por la monarquía ${ }^{26}$. Además, aún no se verificó si los fidalgos y caballeros de las Órdenes Militares recurrían al status de noble para obtener ventajas

23 Felices de la Fuente, 2012, pp. 325-348; Brading, 1991, p. 283; Ladd, 1976, pp. 13-23; Büschges, 1999, pp. 215-231; LiRA MonTt, 1981, p. 635.

24 Felices de la Fuente concuerda con Doris LAdD al aseverar que "todos los ricos eran títulos", $2012, \mathrm{p}$. 333.

25 KicZA, 1982, p. 449. Para Quito, se verificó que las familias importantes no tenían títulos y algunas familias con títulos tenían problemas financieros, ver: BüsCHGES, 1996, p. 177 y 178; LANGUE, 1992; 1999 , p. 288.

26 Sobre la fragilidad de los linajes, véase SchwarTz, 1988, p. 228-230. 
en el control de los puestos administrativos y beneficios económicos como lo hacían las "grandes familias" en la Nueva España. De todas maneras, por un pequeño lapso de tiempo, los caballeros de la Orden de Cristo estaban exentos de los diezmos. Así, aunque no haya un estudio advirtiéndolo, en Brasil se concebía la nobleza de forma tradicional, para disimular la calidad o, incluso, para comprobar que no tenía sangre impura y origen villano.

En Portugal, los hábitos y las "comendas" eran honores reales concedidos a los vasallos que se destacaban sobre todo en los servicios militares. En la expectativa de recibir la honra, los antiguos y los nuevos guerreros se comprometían en la expansión del norte de África y la India, defendiendo los intereses de la Corona. Trazaban entonces estrategias de ascenso social pautadas en el recibimiento de tales privilegios. Muy pronto, las capitanías de la América portuguesa y del Atlántico sur se afirmaron como áreas estratégicas. La caída de las plazas orientales y las guerras contra los holandeses valorizaban los servicios prestados por los habitantes de Brasil. En este sentido, las guerras de Pernambuco rindieron a sus habitantes honras nunca antes $\operatorname{vistas}^{27}$.

Los estudios sobre las Órdenes Militares en Brasil tuvieron dos enfoques básicos. Primero, se dedicaron al análisis de la concesión real de los hábitos y "comendas", principalmente de la Orden de Cristo. En esta etapa, la monarquía valoró los méritos y servicios militares de los habitantes de las capitanías de Pernambuco y Bahía, entre 1640 y 1680 . Entre los beneméritos se destacan los miembros de la "açucarocracia" (señores de los ingenios, los que plantaban caña y sus parientes), los militares de carrera y los comerciantes. Más allá de los hábitos y las pensiones, las guerras de Pernambuco rindieron a los principales militares (nueve habitantes de Bahía y Pernambuco) las "comendas" de las Órdenes Militares, prestigiosas honras de la monarquía portuguesa ${ }^{28}$. Sin embargo, las "comendas" servían para remunerar militares que no siempre estaban insertos entre las elites tradicionales. En este sentido, cabe mencionar al jefe indígena Antônio Felipe Camarão y al mulato João Fernandes Vieira, quienes recibieron "comendas" de la Orden de Cristo en el reinado de D. João IV. Luego, las investigaciones se enfocaron en el período llamado "pombalino" (17501777) y demostraron una alteración sustantiva en la concesión de los hábitos de las Órdenes Militares. En esta etapa, los habitantes del reino y de ultramar, principalmente militares y comerciantes, se convirtieron en caballeros por medio de la compra de la comprobación de los servicios militares y del perdón real para los oficios mecánicos o viles. Para incentivar el comercio y las finanzas de la monarquía, el gobierno "pombalino" prometió el perdón y hábitos mediante la compra. Para ello, tenían que adquirir 10 acciones de la Compañía de Grão-Pará y Maranhão o de la Compañía de Pernambuco y Paraíba; o entregar ocho "arrobas" de oro anualmente en las Casas de Fundición de la Capitanía de Minas Gerais. Cabe mencionar que en esta misma época también proliferó la práctica de venta de títulos de nobleza en la América española ${ }^{29}$.

\footnotetext{
27 Dutra, 1999; Olival, 2001, p. 53.

28 Krause, 2012.

29 Olival, 1998-1999; Stumpf, 2009; Felices de la Fuente, 2012, pp. 326-365.
} 
En las Indias de Castilla, la Orden de Santiago era la más prominente y armó en el siglo XVII 281 nuevos caballeros, pero concentró la distribución en dos períodos, entre 1641 y 1650 (50 nuevos caballeros) y entre 1691 y 1695 (26). En el siglo XVIII, en general, la distribución de los hábitos de las Órdenes perdió el ímpetu anterior, cayó hasta 198 nuevos caballeros, pero alcanzó índices altos entre 1786 y 1790 (24). Sin embargo, a finales del siglo la Orden de Carlos III distribuyó un número elevado de hábitos a los habitantes de las Indias, pues entre 1786 y 1800 se armaron 111 caballeros. Por estas fechas, las guerras en Europa (contra Cataluña, Portugal y Francia) fueron la principal razón para que el rey hiciera merced de hábito a los americanos. En relación a la geografía, el estudio de Lohmann Villena reafirma el predominio de Lima y de Nueva España como las áreas de mayor concentración de caballeros. Entre los siglos XVI y XIX, en la primera se armaron 230 caballeros de la Orden de Santiago y 93 de la Orden de Calatrava, mientras que en toda Nueva España estos números fueron inferiores, 105 y 23 respectivamente. Además, Lima también era la ciudad de mayor incidencia de nobles titulados del Nuevo Mundo ${ }^{30}$.

Desgraciadamente no existe en Brasil una investigación tan completa. De todas maneras, cabe mencionar los dos estudios parciales existentes referidos a los espacios y tiempos más restringidos. Entre los años 1641 y 1683, la Orden de Cristo concedió, como remuneración de los servicios militares contra los holandeses, 169 hábitos de caballeros a los habitantes de las capitanías de Pernambuco (84) y Bahía (85). En Minas Gerais, se encontraron solamente 42 títulos concedidos después de 1750, a cambio de 8 arrobas de oro ${ }^{31}$. Al comparar los números de Lohmann y Krause, se percibe que las guerras contra los holandeses (1630-1654) tuvieron como consecuencia el ofrecimiento de muchas honras. Sin embargo, cualquier esfuerzo por evaluar la difusión de los caballeros de las Órdenes Militares en las Américas enfrenta aún una incipiente investigación en el caso brasilero.

\section{INDIOS Y MULATOS EN LAS ÓRDENES MILITARES}

Para la doctrina oficial de la Iglesia Romana, los amerindios no eran infieles, sino gentiles, una condición primitiva de los católicos antes de la evangelización. A diferencia de los judíos y los moros, los nativos del Nuevo Mundo desconocían la palabra revelada y jamás podrían ser encuadrados como herejes o apóstatas. De esta forma, los indios que disfrutaban de la pureza religiosa no eran infieles y tampoco podían ser víctimas de los inquisidores. Sin embargo, ellos estaban excluidos del sacerdocio y de algunos oficios religiosos, sin contradecir el discurso oficial sobre la pureza de su sangre. En suma, para la Iglesia, los indios no eran cristianos antiguos, tampoco eran cristianos nuevos, estaban en una especie de limbo ${ }^{32}$.

El debate mencionado no tuvo tanta repercusión en Portugal y los amerindios obtuvieron allí algunas mercedes concedidas a los hombres de calidad. Con la falta cró-

\footnotetext{
30 Lohmann Villena, 1993, p. LXXIV-LXXV.

31 Krause, 2012, p. 132; Stumpf, 2009, p. 287.

32 Raminelli, 2013; Martínez, 2008, p. 103.
} 
nica de tropas portuguesas para enfrentar las invasiones holandesas en Pernambuco, Maranhão y Angola, los gobernantes luso-brasileros se valieron de fuerzas militares indígenas. En este sentido, cabe mencionar que nueve jefes indígenas se volvieron caballeros de las Órdenes Militares. Ellos enfrentaron con éxito las probanzas y se consagraron puros de sangre y libres de máculas. Entonces recibieron el hábito como una remuneración de los servicios de guerra contra los holandeses, negros e indios rebeldes. Aunque no fueran numéricamente importantes, los indígenas ascendidos a caballeros demostraron lo maleable que era la idea de nobleza en Portugal. De hecho, la absorción de los jefes indígenas por las Órdenes Militares ocurrió en coyunturas críticas para la monarquía portuguesa: la invasión francesa de la Bahía de Guanabara - Río de Janeiro (1555-65); la guerra contra los holandeses en Pernambuco y Angola (1630-54); la llamada guerra de los bárbaros - contra los indios del interior (c. 16901710). En los tiempos de guerra, aumentaron sensiblemente las concesiones de hábitos. Ciertamente en la monarquía lusitana, después de la unión dinástica, la valentía era más importante que la sangre. ¿Pero estos militares y nobles indígenas gozaban de los mismos honores acumulados por los otros luso brasileros?

En la Bahía de Guanabara, el jefe indígena Araribóia, bautizado Martim Afonso de Souza, enfrentó a los franceses al lado de Mem de Sá. Aunque con un nombre cristiano, él era un gran guerrero tupi y como los demás, un caníbal. Aún así, recibió como recompensa de D. Sebastião, en 1571, el prestigioso hábito de la Orden de Cristo, además del nombramiento de capitán-mor de su aldea. Consciente de su valor para el gobierno de la capitanía, Araribóia seguramente disputó puestos militares para sus familiares. Después de 1638, en la Capitanía de Pernambuco, Antônio Felipe Camarão, héroe indígena de la guerra contra los holandeses, recibió el título de Don, escudos de armas, patentes militares, hábitos y encomiendas de la Orden de Cristo ${ }^{33}$. Durante la guerra contra los holandeses, Felipe III y D. João IV prometieron hábitos de las Órdenes Militares y perdonaron las máculas de dos indios, un mulato y un mameluco: Manuel de Sousa, Diogo Pinheiro Camarão, Manuel Gonçalves Dória e Bento Maciel Parente. Curiosamente, estos individuos eran oriundos de puntos diferentes de la América portuguesa: Río de Janeiro, Pernambuco, Bahía y Cabo Norte/Maranhão, respectivamente. Sin embargo, no todos se consagraron caballeros, aún cuando tuvieron la posibilidad de recibir el hábito, porque no dieron seguimiento al proceso, o por no haber recibido la habilitación de la Mesa de la Consciencia y Órdenes ${ }^{34}$.

En suma, entre 1571 y 1721, la monarquía portuguesa concedió a los jefes indígenas los hábitos de las Órdenes Militares por sus valerosos servicios militares. La distribución de los privilegios entre los jefes indígenas era, sin embargo, un tema largamente debatido en la Mesa de la Consciencia y Órdenes en la que no siempre se concordaba con la merced de los hábitos concedidos por los monarcas. Para el indispensable mantenimiento del imperio, la liberalidad real ampliaba las alianzas entre la Monarquía y sus fieles vasallos ultramarinos. Al premiar las hazañas militares, los reyes multiplicaban sus defensas y aseguraban el control sobre sus territorios.

33 Carta de hábito de Martim Afonso de Sousa. Lisboa, 30-XI-1571. ANTT. Lisboa, Chancelaria da Ordem de Cristo, livro 02, fol. 84 v. Raminelli, $2013 \mathrm{a}$.

34 Raminelli, 2012. 
La monarquía concedía los privilegios a los que habían servido y ofrecían servir en la guerra. Así, la princesa Margarida defendía que esto podía hacerse sin escrúpulos, pues las "comendas fueron instituidas como premios militares por lo cual no quedan dudas sobre esta materia" 35 . Justificaba de esta manera la concesión de los privilegios a los valientes guerreros, súbditos que no siempre presentaban las calidades necesarias para ingresar en las Órdenes Militares.

En los estudios sobre los americanos en las Órdenes Militares, Lohamnn Villena mencionó la concesión de títulos nobiliarios a las familias descendientes de los nobles incas y mexicas. Es más, la Cédula del 26 de marzo de 1697 estableció la equivalencia de los descendientes nobles indígenas a los hidalgos de Castilla. Desde entonces ellos podían utilizar el sobrenombre de Don y ampararse bajo los mismos privilegios $^{36}$. Por supuesto este reconocimiento fue bien tardío y no abarcaba a los principales aliados españoles de la conquista del siglo XVI. A lo largo del estudio, Lohmann no aclaró si los caballeros mencionados eran indígenas castizos, descendientes exclusivos de la nobleza prehispánica. Sin embargo, creo que tales caballeros de las Órdenes Militares no eran indígenas de los cuatro costados como sucediera en la América portuguesa, sino vástagos originados en los casamientos mixtos entre los conquistadores castellanos y la nobleza indígena.

Cabe mencionar dos ejemplos notorios de caballeros mestizos. Armado caballero de la Orden de Santiago en 1620, Diego Cano Moctezuma era nieto del castellano Don Juan Cano Saavedra, nacido en Cáceres, y de Doña Isabel Moctezuma, hija del monarca mexica. Tal vez Diego Cano fuera el primer descendiente de la realeza de México en recibir la mencionada honra real. Aun siendo natural de Cuzco y descendiente inca, Don Melchor Carlos Inga utilizaba el título de Don antes de la cédula de 1697. De hecho, su abuelo, Don Cristóval Paullo Topa Inga, era el hijo menor de Huayna Capaj, emperador inca, aunque la madre de Don Melchor era una castellana de Trujillo. Él se convirtió en caballero de la Orden de Santiago en 1606, bien antes de que el descendiente de Moctezuma fuera declarado caballero. Lohmann también menciona la existencia de más de ocho mestizos armados caballeros de la Orden de Santiago $^{37}$. Aún siendo reconocido su origen prehispánico, a nadie se le escapó el mestizaje con los castellanos. Entonces, se concluye que aunque no tuviesen sangre impura, los amerindios no eran suficientemente puros para recibir títulos de caballeros. Sus descendientes podrían ser caballeros de las Órdenes Militares solamente después de que la sangre castellana limpiase totalmente las "impurezas americanas" originadas en el casamiento entre los conquistadores y "las princesas incas y mexicas". Mientras tanto, en la América portuguesa, los negros y mulatos fueron impedidos por la Mesa de Consciencia y Órdenes de recibir las honras prometidas por los monarcas en función de sus hazañas militares. A Henrique Dias ${ }^{38}$, héroe negro de las guerras de Pernambuco, los reyes le ofrecieron a partir de 1638, la merced de un hábito de una de las tres Órdenes Militares, una "comenda", 40 escudos de sueldo y el fuero de

35 Carta da Princesa Margarida. Lisboa, 26-XII-1635. ANTT. Lisboa, Mesa da Consciência e Ordens, Ordens Militares, Papéis Diversos, maço 20 n. 182. Ver también el documento n. 183.

36 Lohmann Villena, 1993, tomo 1, pp. XVIII, 76, 199 y 200.

37 Lohmann Villena, 1993, tomo 1, pp. 68, 76, 111, 142, 198-199 y 446-447; tomo 2, pp. 34, 179 y 314.

38 Raminelli, 2013; Dutra, 1999; Vasconcelos, 1940; Mello, 1967. 
fidalgo. Durante el gobierno de los Bragança, los diputados de la Mesa no se dejaron llevar por el entusiasmo del rey e, inicialmente, solicitaron al benemérito la petición formal de la honra. Luego, insistieron en que las probanzas eran indispensables, de lo contrario la entrega del hábito se haría mediante el breve apostólico de despido. Por impedimento de la Mesa de ser convertido en caballero, Henrique Dias no recibió las honras prometidas. Solamente en 1657, la reina D. Luisa de Gusmão mandó pasar un nuevo permiso al fuero de fidalgo y, en el año siguiente se le concedió la patente de "mestre de campo ad honorem" ${ }^{39}$. Él también pidió a la reina que la "comenda" del Moinho de Soure, que recientemente le fue concedida, fuera pasada a su yerno, Pedro de Valdoveço, "una persona muy noble", con la promesa de casarse con su hija Dona Guiomar. En Lisboa, sus pedidos no fueron aceptados en su totalidad y las pensiones para sus yernos fueron muy reducidas. Muy pobre, en Lisboa, el "mestre de campo" no contaba con los recursos para los gastos con la Cancillería. Por eso, recurrió nuevamente a la reina solicitando recursos no sólo para pagar las tasas, sino también para "preparar las provisiones que sean necesarias para cuando tenga que volver para dicha Capitanía"

Desde la segunda mitad del siglo XVII hasta inicios del siguiente, a los compañeros de guerra de Henrique Dias se les negaron sus peticiones de hábito de caballeros debido a la irrelevancia de sus hazañas y por haber sido esclavos. La Mesa de Conciencia y Órdenes difirió el pedido por haberle parecido injusto que una persona "tan indigna de la estima de las personas como lo es un negro" usara el hábito de São Bento de Avis ${ }^{41}$. Los dos factores fueron determinantes para impedir que la merced real fuera concretada. Como consecuencia, se percibe que los rechazos de la Mesa de la Consciencia y Órdenes se intensificaron a partir de la segunda mitad del siglo XVII, al mismo tiempo que se intensificó el tráfico de esclavos. Además, varios negros y mulatos recibieron hábitos en las primeras décadas del siglo XVII, según el estudio de Francis Dutra ${ }^{42}$. Entonces debemos considerar que la relación entre el aumento del tráfico y del empleo de esclavos en América y en Portugal, fueron factores capaces de transformar negros y mulatos en razas impuras, pues inicialmente esta categoría abarcaba apenas a los descendientes de judíos y moros. Sin embargo, se debe destacar que, después de 1670 , los peligros de la guerra cedieron y ya no existía tanta dependencia de la Corona con relación a sus aliados sin calidades. A partir de esta nueva coyuntura, la remuneración de los servicios de los negros y los indios cayó de forma sustancial.

Revisando las mercedes de hábitos y las probanzas de las Órdenes Militares, se percibe que había una gran posibilidad de convertir en nobles a los indios, en cuanto que para los negros y mulatos estos honores estaban vedados. Esta importante conclusión explica en gran parte los factores responsables de convertir un mestizo (mameluco) como Bento Maciel Parente en caballero, favorecido con tantos honores

39 "Henrique Dias mestre de campo" en VAsconcelos, 1940, p. 35. Cabe mencionar que no encontré el registro del fuero de fidalgo concedido a Henrique Dias.

40 “O governador Henrique Dias" en VASCONCELOS, 1940, pp. 24-26.

41 Habilitação de Domingos Rodrigues Carneiro. Lisboa, 30-IV-1688. ANTT. Lisboa, Habilitação da Ordem de Avis, letra D, maço 1, número 1.

42 Dutra, 2011, p. 103. 
por los soberanos. Si los jefes indígenas estaban libres de los obstáculos de la sangre, a los mestizos, hijos de portugueses con indias, la Mesa de la Consciencia y Órdenes no podía imputar la mácula de la impureza de sangre. Hijo de gobernador, fidalgo y caballero de la Orden de Cristo, el origen de Bento Maciel Parente también propiciaba su ascensión a caballero.

La lógica familiar era también válida para los mulatos. Por su origen cautivo y gentil, los mestizos tenían grandes posibilidades de que les fueran negadas sus solicitudes para ingresar en la Inquisición como familiares y también en las Órdenes Militares. Sin embargo, Matias Vidal de Negreiros, hijo bastardo y mulato de André Vidal de Negreiros, recibió de Su Majestad el hábito de la Orden de Cristo y foro de fidalgo ${ }^{43}$. Para ello, también obtuvo de la corona otra honra: la legitimación de su paternidad, aún después del fallecimiento de su padre. En este caso, el hecho de ser mulato y de ser bastardo no impidió que el hijo de André Vidal de Negreiros, héroe de las guerras de Pernambuco, recibiera más allá del prestigioso hábito, la patente de sargento-mor y capitán honorífico en $1694^{44}$.

\section{PRIVILEGIOS DE NOBLES Y CIUDADANOS}

Más allá de su origen y de sus virtudes, hay que destacar que la definición del noble castellano estaba profundamente vinculada a los privilegios fiscales, jurídicos y políticos. Sin embargo, en la América hispánica, la distinción entre nobles y las personas comunes no se debía a la excepción de pagar "pechos y tributos", pues solamente las comunidades indígenas los pagaban ${ }^{45}$. Además, el fuero eclesiástico de los caballeros les permitía enviar los diezmos directamente a las Órdenes de la península, exención que no siempre era respetada y que provocó mucho litigio a lo largo del período colonial. En el ámbito de la justicia, los caballeros gozaban de un fuero especial, juzgado por los jueces conservadores indicados por las Órdenes, un privilegio judicial que no sobrevivió en el Nuevo Mundo. En principio, el debate se daba sobre el fuero de los caballeros: ¿eran los profesos de las Órdenes Militares religiosos o seculares? Más allá de esta duda, no siempre era factible nombrar jueces especiales para las Órdenes radicadas en la península. Finalmente, cabe mencionar que la Corona temía reforzar el fuero privilegiado en tierras tan distantes, como recordó Lohmann Villena ${ }^{46}$. En

\footnotetext{
43 Habilitação de Mathias Vidal de Negreiros. Lisboa, 20-XII-1690. ANTT. Lisboa, Habilitação da Ordem de Cristo, letra M, maço 48, doc. 19; Alvará. Foro de Fidalgo cavaleiro de Mathias Vidal de Negreiros. Lisboa, 1-II-1691. ANTT. Lisboa, Registro Geral das Mercês de D. Pedro II, liv. 6, fl. 294-294v.

44 Carta de Sargento mor. Lisboa, 4-XII-1694. ANTT. Lisboa, Registro Geral das Mercês de Pedro II, liv. 9, fl. 209. Carta patente capitão honorífico. Lisboa, 11-XII-1694. ANTT. Lisboa, Registro Geral das Mercês de Pedro II, liv. 9, fl. 209v. Sobre los servicios militares de los demás mestizos, véase Raminelli, $2013 \mathrm{a}$, pp. 291-312.

45 Lira Montt, 2010, pp. 35-56; Guillén Berrendero, 2008, p. 270.

46 "La inmunidad requería para su recto ejercicio reconocimiento expreso o tácito, mas a todo se resistió la Corona, temerosa de que una nueva jurisdicción especial emulara la indiscutible autoridad real, lograda tras duro y áspero batallar contra levantiscos los caudillos que se sublevaban, poderosos encomenderos o ensoberbecidos gobernadores”. Lohmann Villena, 1993, p. XLII.
} 
suma, las inmunidades de los nobles americanos generaban ciertamente fuerzas centrífugas, razón para cancelar este privilegio de los caballeros americanos.

En la América portuguesa, los comendadores, los caballeros de las Órdenes Militares, los desembargadores, fidalgos, oficiales de guerra, familiares del Santo Oficio, entre otros, estaban exentos de diezmos. Sin embargo, a partir de 1645, los camaristas de la ciudad de Salvador de Bahía escribieron muchas veces a los soberanos para que suspendieran este privilegio ya que tenían una gran necesidad de capital. Con la amenaza del retorno de los holandeses, la reina D. Luísa de Gusmão necesitaba que los habitantes de Bahía pagasen los donativos y la contribución para el mantenimiento de la infantería. Los ediles también destacaban que eran los más ricos, los dueños de las más extensas propiedades, los que estaban exentos del pago de los diezmos. En Bahía, Paraíba y Pernambuco, la resistencia de la nobleza local se prolongó por muchos años, ya que existen denuncias fechadas en 1663 contra el no cumplimiento de la ley por parte del poderoso comendador mulato de la Orden de Cristo João Fernandes Vieira. Solamente el 10 de octubre de 1657, la Mesa de la Consciencia y Órdenes realizó una consulta en la que declaraba la exención como un privilegio apenas para los religiosos que vivían en conventos y monasterios. El Consejo Ultramarino concordó plenamente con la decisión de la Mesa el 6 de febrero de 1658. En esta determinación quedaba claro que los caballeros deberían pagar diezmos para defender la conquista frente a los holandeses, así como es mencionado en el estudio de Thiago Krause ${ }^{47}$.

De todas maneras, cabe destacar que no es raro que las investigaciones apunten las debilidades de las libertades y exenciones de la nobleza americana. Aunque hubiese privilegios observados y reclamados, ellos no se fundamentaban en una legislación propia de ultramar y eran administrados según usos y costumbres de Castilla, como asegura Christian Büschges. El usufructo de los privilegios variaba según las coyunturas y las diferencias regionales, dependiendo de las disputas políticas en las Audiencias ${ }^{48}$. Del lado portugués, se observaban privilegios aún más restringidos y a veces incapaces de diferenciar el liderazgo de los caballeros frente a los hombres ricos pero de origen humilde. Vale la pena recordar que los jefes indígenas ascendidos a caballeros y a comendador no se insertaban en la primera nobleza colonial, jamás entraron en los puestos militares de mayor prestigio y tampoco en las câmaras municipales y de las Santas Casas de Misericordias, instituciones donde se reunían los beneméritos del seiscientos ${ }^{49}$.

En las Indias, los castellanos se dividían en conquistadores, habitantes y vecinos, pero solamente los últimos tenían voz y voto en los cabildos, según la Real Cédula de Carlos V (1554). En principio, se alcanzaba la vecindad por las proezas militares realizadas en nombre de la monarquía, pero a lo largo del tiempo se incluyeron otros servicios. Para establecerse como vecino, los nuevos habitantes realizaban la petición de vecindad donde los súbditos garantizaban y comprobaban su interés de permanecer en la región, demostraban su capacidad de comprar tierras (privilegio exclusivo de los vecinos), y de actuar en el cabildo o de conseguir allí un cargo no electivo.

\footnotetext{
47 Krause, 2012, pp. 133- 152.

48 Büschges, 1996, p. 172.

49 Raminelli, 2012; Krause, 2012, pp. 232-246.
} 
Después de aprobados, estaban habilitados no solamente para ocupar oficios capitulares y disponer de recursos materiales, sino también para disfrutar bienes simbólicos: honores, privilegios, libertades y exenciones.

Mientras tanto, Ponce Leiva aseguró que las vías legales no siempre eran determinantes para excluir a los habitantes del poder local. Para la incorporación de un español a los cuadros municipales, existían otras variables, aun cuando fuera importante la vecindad. Las calidades necesarias para ingresar en el cabildo tuvieron múltiples facetas, pero ninguna era capaz de excluir o incluir un habitante. Más allá de la vecindad, los cabildantes eran encomenderos, ricos, honrados y no estaban vinculados a las profesiones del vulgo o manuales. Alejado del reino, entre los indios y mestizos, la integración formal a la comunidad castellana funcionaba como un título honorífico, capaz de promover tanto el honor y el privilegio como los beneficios materiales. Para Lira Montt, los cabildos eran los núcleos más representativos de "Estado Noble" en América. Los cargos de alcaldes y regidores conferían entonces nobleza personal a quienes los ejercieron ${ }^{50}$.

En la América portuguesa, los "cidadãos" (ciudadanos) controlaban el poder municipal actuando como "vereadores, procuradores, juízes ordinários e almotacés". Frecuentemente ellos procedían de los conquistadores y formaban las "mejores familias de la tierra". Sirviendo al monarca en las guerras de conquista contra los indígenas o franceses, los primeros beneméritos de Pernambuco, Bahía y Río de Janeiro pasaron a ocupar cargos en la câmara, "ouvidoria" (defensoría) y "provedoria" (proveduría) de la Hacienda Real. Así, los "hombres de bien" -otra denominación para los ciudadanos- se transformaban en capaces de controlar tierras, esclavos, plantaciones e ingenios de azúcar. En Río de Janeiro, los cargos de las câmaras permitían a los conquistadores y sus descendientes intervenir en el mercado, controlar precios y servicios ligados al abastecimiento de la ciudad, el transporte para el reino y el precio del azúcar. Así, recurriendo a la remuneración por las proezas de la conquista, ellos generaban una nueva sociedad. Haciendo uso de sus cargos y redes de alianzas, aseguró Fragoso, "ellos construyeron ingenios y con eso se convirtieron en la primera elite señorial de la sociedad colonial de Río ${ }^{51}$. Ellos actuaban como "nobles de la tierra", sin contar necesariamente con bastos capitales u origen fidalgo. Se percibe aquí una semejanza en la forma de montar los poderes locales en la América hispánica y la portuguesa, aunque los cargos de los cabildos no transformasen a los ediles en nobles.

En el siglo XVII, más precisamente entre 1642 y 1662, las ciudades de Río de Janeiro, Salvador, São Luís, Belém y Luanda recibieron como remuneración de la guerra contra los holandeses, los privilegios de la ciudad de Oporto ${ }^{52}$, tales como libertad y exenciones muchas veces semejantes a las disfrutadas por la fidalguia. Desde entonces, los ciudadanos -aquellos que ejercieron cargos en la câmara-y sus descendientes disfrutaban de algunos privilegios. Ellos no podían ser sometidos a castigos, tampoco podían ser presos en la cárcel, solamente podían estar presos en sus residencias. Podían también portar armas por la noche, debido a sus calidades en las formas

50 Bayle, 1952, p. 125; Ponce Leiva, 1996, p. 111; Lira Montt, 2010, p. 92.

51 Fragoso, 2001, p. 70 y 2007, pp. 33-120.

52 Privilegios dos cidadãos da Cidade do Porto, 1611, pp. 17-26. 
en que se debe ser y son fidalgos de esos reinos. Sus criados, labradores y patrimonio jamás podrían ser confiscados contra su voluntad. Además, guardaban en sus casas -y lo que se encuentra dentro y fuera de ellas- todas las libertades que antiguamente tenían los Infanções y los hombres ricos ${ }^{53}$. Al servir en los cargos honoríficos de la República, los hombres de bien de la câmara pasaban a cuidar sus posiciones en las ceremonias, las festividades, misas y procesiones en donde debían ocupar los lugares propios de la nobleza. Más allá de los mencionados privilegios, ellos eran inmunes a cualquier intento de la Corona de convocarlos en las ocasiones de conflictos bélicos. Estos privilegios que estaban garantizados a los ciudadanos amenazaban el control portugués sobre los territorios codiciados por los rivales europeos. Al negarse a defender los territorios, los ciudadanos algunas veces entraban en conflicto con los gobernadores u otros oficiales reales ${ }^{54}$. Este privilegio no tuvo una larga vida, pues amenazaba la ya debilitada defensa.

Siguiendo la relación de ventajas, se percibe que los privilegios de la câmara de Oporto no actuaban sobre la exención o reducción de los impuestos, aunque la câmara pudiese estipular los precios y valores de los servicios - poder que también cayó en desuso a mediados de los setecientos-. Desde 1658, cuando la Mesa de Consciencia y Órdenes y el Consejo Ultramarino aprobaron la cobranza de los diezmos a los caballeros de la Orden de Cristo, la nobleza americana no contaba más con este tipo de privilegio. Así, volviendo al tema inicial de este artículo, se entiende que el interés de la cámara de Río de Janeiro de registrar las mercedes reales para identificar los verdaderos nobles y cohibir la propagación de impostores no era relativo al fisco, o sea, relativo a los privilegios fiscales de los nobles.

Como los oficiales de la câmara vigilaban por la "gravedad de las cosas", la jerarquía social instituida por la monarquía, según la carta dirigida a Su Majestad, garantizaba también la limpieza de la sangre de los oficiales. En la carta real del 13 de abril de 1636, el monarca recomendaba que fueran limpias de sangre las personas que ocuparan cargos en el gobierno o en la justicia. Por lo tanto, no convenía dar a los hombres de la nación hebrea "honores, ni lugares públicos, ni cargos en el gobierno, ni en la Justicia", ni los puestos donde se concedían las mercedes, ni dentro de la Real Hacienda ${ }^{55}$. Sin embargo, en las últimas décadas del seiscientos, los oficiales de la câmara de Río de Janeiro escribieron al monarca para denunciar la elección de cristianos nuevos para el senado de la ciudad. Por tanto, acusaron al ouvidor Manoel de Sousa Lobo de haber provocado la elección de personas impuras, como lo indica Fernanda Bicalho. Enviaron a Lisboa al procurador de la câmara para expulsar tanto a los descendientes de los hebreos como a las personas con alguna mácula. Consciente de la gravedad del conflicto, el monarca determinó la anulación de la mencionada elección en diciembre de $1697^{56}$.

53 Sobre los pedidos de privilegios, véanse: Consulta do Conselho Ultramarino. Lisboa, 9-X-1644. AHU, Lisboa, Rio de Janeiro, Castro Almeida, doc. 334.

54 Bicalho, 2003, pp. 322-332.

55 Carta dos oficiais da Câmara do Rio [de Janeiro], ao rei [D. João V]. Rio de Janeiro, 8-VII-1726. AHU, Lisboa, Rio de Janeiro, avulsos, doc. 1861. Collecção Chronologica, 1819, t.1, p. 68.

56 BicalHo, 2001, p. 213. 
El mantenimiento de la pureza de sangre y del honor no era una explícita manifestación religiosa. En esa perspectiva, cabe mencionar los estatutos municipales de limpieza de sangre y de la nobleza en Castilla. En muchos municipios peninsulares, ellos fueron implementados solamente en el siglo XVIII. Además, Enrique Soria consideró tal política no como una estrategia para impedir la entrada de los cristianos nuevos, sino para facilitar el acceso a los amigos, familiares y clientes y también para promover "a los ojos de la sociedad su poder adornándose con los atributos de una nobleza de sangre de la que la gran mayoría distaba mucho de pertenecer" ${ }^{57}$. $\mathrm{Al}$ exigir pureza religiosa, los hombres de bien de la câmara dificultaban la entrada a los forasteros y también cuidaban la reputación del poder municipal. Lo cual aumentaba su legitimidad y capacidad de intervención política.

Así, los oficiales de las câmaras importantes de la América portuguesa se nombraban y se trataban como nobles y exigían honores equivalentes. En 1664, dos camaristas aseguraron que solamente los fidalgos deberían ser admitidos en la cámara de Río de Janeiro, como forma de mantener la calidad de los hombres de bien. En general, los ediles tenían nobleza política y civil, calidad concedida por los príncipes a los vasallos que demostrasen lealtad y méritos. Actuaban como hombres singulares, virtuosos, ricos, elocuentes o valientes en la guerra o en la administración de la república ${ }^{58}$.

En 1711, la câmara de Olinda, cuna de la aristocracia azucarera, estaba en conflicto con la recién creada câmara de Recife, una villa portuaria dominada por los comerciantes del reino. En carta al Rey, "los oficiales de la câmara y la nobleza" recordaban al monarca los servicios prestados, fueran en la guerra de la conquista contra los indios, fuera en la liberación de Pernambuco del yugo holandés. En estos episodios, los pernambucanos demostraron al soberano que eran los mejores y los más fieles vasallos del imperio. Desde hacía mucho tiempo, sus padres y sus abuelos lucharon con valentía para mantener la capitanía bajo el dominio de la monarquía portuguesa. Solicitaban el reconocimiento por sus hazañas y su lealtad. Aún cuando los ediles se oponían a las ventajas concedidas a los comerciantes reales, la reacción de los nativos pernambucanos, según Evaldo Cabral de Mello, estaba marcada por la lealtad al soberano y jamás desobedecerían la orden colonial ${ }^{59}$. Cabe mencionar que aunque enfrentaran la guerra con sus vidas y propiedades, los ciudadanos de Olinda no recibieron los privilegios de la câmara de Oporto como así lo hicieron las importantes ciudades del litoral.

Más allá de elevar su nivel social, los privilegios otorgados a los hombres de bien, fueron un triunfo importante en los conflictos políticos con los gobernadores y oficiales reales. En la Capitanía de Río de Janeiro, el juego político tal vez se convirtiese más importante en la preservación de los honores propios de la nobleza. Con este triunfo, los ediles tenían mejores condiciones para negociar con los estratos superiores de la administración colonial y central. El cuidado con las jerarquías tal vez explique la solicitación al monarca para que fuese obligatorio el registro de los títulos, hábitos y escudos de armas, o sea, la preservación de la orden estamental. De hecho,

57 Soria Mesa, 2013, p. 17.

58 Representação dos oficiais da Câmara do Rio de Janeiro. Rio de Janeiro, 23-II-1664. AHU. Lisboa, Rio de Janeiro, Castro Almeida, doc. 974; VerA, 2005, pp. 20-23.

59 Mello, 1986, p. 118. 
en varios episodios registrados en las actas de las câmaras y en la correspondencia emitida al rey o al Consejo Ultramarino, quedaba evidente la necesidad de hacer cumplir los privilegios de la câmara de Oporto concedidos a los hombres de bien.

En nombre de los ciudadanos, el procurador de la câmara Julião Rangel de Souza Coutinho, escribió al rey, en febrero de 1730, para denunciar la violencia e injurias practicadas por el gobernador de la capitanía. Los "vasallos de América" fueron punidos sin apelaciones, sus recursos fueron frecuentemente rechazados y tampoco podían valerse de la administración de justicia. No era extraño que los daños provocados por el gobernador quedaran sin castigo, pues el soberano no estaba informado sobre los desmanes perpetrados en la Capitanía de Río de Janeiro. Los habitantes con riquezas veían su patrimonio amenazado y temían vivir miserablemente. Inicialmente la representación de los oficiales enumeró los desmanes del gobernador no solamente contra los ciudadanos, "vasallos de América" y sus habitantes, sino también contra "el País y el Estado". En suma, el documento intenta demostrar que la violencia y el despotismo del gobernador influenciaban a todos. Sin embargo, el relato gana mayor ininteligibilidad cuando se sabe que el grupo victimizado por el despotismo estaba constituido por los hombres de bien.

Los oficiales pedían que el gobernador no se entrometiera en la administración de la justicia, imponiendo penas graves y ajenas a las leyes del reino. También, la carta menciona que el gobernador no obedecía las leyes extravagantes que determinaban la imposibilidad de arrestar a las personas del gobierno, ni a sus ciudadanos, ni a los habitantes que no fueran militares fuera de los actos de guerra. El gobernador tampoco podría entrometerse en las cosas de la justicia, en los acuerdos y determinaciones de la câmara. Al final de la representación, se evidencia el grave conflicto entre el gobernador y los ediles. Cabe mencionar que en 1732, el gobernador Luís Vaia Monteiro fue depuesto por la câmara por no estar en su sano juicio ${ }^{60}$.

El incidente mencionado se suma a los conflictos entre los ciudadanos y los comerciantes. De hecho, el equilibrio político de la ciudad se alteraba al saber los descubrimientos de las minas y del aumento del flujo comercial en el Atlántico sur. La ciudad de Río de Janeiro creció rápidamente, y los ciudadanos pasaron a disputar el poder con los comerciantes ricos. En el interior de la câmara, ellos eran controlados por el juiz de fora, magistrado promovido por la monarquía y, en principio, ajeno a las parentelas locales. Más allá de enfrentar a los gobernadores y de perder el control de algunos oficios reales, los ediles ya no dictaban más el precio del azúcar y enfrentaron a los comerciantes que amenazaban entrar en la câmara. Los ciudadanos, sin embargo, se afirmaron todavía más en los puestos municipales desde donde podían dictar algunas reglas para el mercado local. Hasta mediados del siglo XVIII, las familias descendientes de los conquistadores controlaban cerca del 70\% de los oficios del municipio. Por medio de los casamientos y de las agrupaciones, los linajes del quinientos, según Fragoso, mantuvieron alejados a los extranjeros de las posiciones influyentes en la sociedad y en la República.

\footnotetext{
60 Requerimento dos oficiais da Câmara do Rio de Janeiro. Rio de Janeiro, 11-I-1730. AHU. Lisboa, Rio de Janeiro, avulsos, doc. 2263; VARnHAGEN, 1981, tomo 5, p. 258.
} 
En las actas de las câmaras, el control municipal se justificaba por la calidad de las principales familias terratenientes, honor que se remontaba a los inicios de la urbe. Trabada en las décadas de 1550 y 1560 , la guerra contra los indios tamoios y franceses convirtió en nobles a los conquistadores, de acuerdo a la perspectiva de los ciudadanos. Además, los privilegios de la câmara do Oporto no vinieron a crear por decreto la nobleza de la capitanía, pues su existencia era anterior a la concesión real. Aunque el primer episodio fuera un gran acontecimiento y concediese antigüedad al grupo, no tenía respaldo jurídico. En esa oportunidad, la monarquía no condecoró a los conquistadores por sus hazañas. Sin embargo, desde la fundación de la villa, ellos y sus descendientes eran "nobles en la práctica" al controlar los principales cargos de la República. Por otro lado, los privilegios de Oporto eran mercedes reales que convertían jurídicamente en nobles a los gobernantes de la ciudad. Mientras tanto, para los camaristas no fue este decreto el que creó a la nobleza ${ }^{61}$. En suma, sus privilegios no eran una concesión real, sino fruto de sus hazañas militares.

De esta forma, para gobernar la ciudad de acuerdo a los oficiales, era indispensable tener la calidad de fidalgo o de personas notables de la nobleza, pues los ciudadanos eran "dos veces nobles" que servían desde hacía mucho a la monarquía. Los forasteros estaban impedidos de entrar en la câmara, sobre todo los comerciantes ricos, por no contar con calidades. La coyuntura de cambios, de conflictos, de amenazas al poder instituido en la ciudad explica mejor las solicitaciones al soberano sobre el carácter obligatorio de registrar los documentos que comprobasen la nobleza para evitar los engaños perpetuados por falsos nobles. Tal vez intentasen crear un obstáculo más, con el aval del soberano, al ingreso de los forasteros en el poder municipal.

\section{CONCLUSIONES}

Las noblezas en América tenían entonces privilegios muy debilitados y constantemente señalados como amenazas al orden colonial. Alejados de la corte, las exenciones fiscales y los fueros especiales se transformaban en poderosas fuerzas centrífugas, enfrentadas tanto por los consejos reales como por los administradores ultramarinos. Más allá de los privilegios, las concesiones de los títulos de nobleza, los hábitos de las Órdenes Militares y el fuero de fidalgo no generaban linajes duraderos. Sin embargo, la idea de linaje noble era más evidente entre los súbditos de la América hispánica, según documentación editada por Lohmann. Las élites coloniales formaban, por lo tanto, grupos inestables, incapaces de sostener el honor o el patrimonio de la familia por muchas generaciones. Quizás la propia condición colonial y la distancia de Lisboa y Madrid generasen trabas para que la nobleza disfrutase plenamente de sus privilegios, del mismo modo que lo hacían los peninsulares.

En Brasil, entre los siglos XVI y XVII, los conquistadores y propietarios de tierras se mantuvieron en el poder de los municipios gracias a las mercedes reales y a la formación de bandos que resistían la renovación del poder local. En la segunda mitad

61 Monteiro, 2009; Fragoso, 2007, p. 47. Sobre el carácter informal y dinámico de la nobleza en Quito, véase BüsCHGES, 1997, p. 52. 
del siglo XVIII, los comerciantes y los traficantes de esclavos ganaron fuerza y se transformaron en grupos poderosos capaces de inmiscuirse en los sectores más altos de la sociedad. Con el avance del comercio, la riqueza se transformó en una referencia indiscutible para medir el poder político de las ciudades ultramarinas, fenómeno también registrado en la América hispánica. De origen humilde y peninsular, los grandes comerciantes y mineros pasaron a comprar la nobleza -títulos y hábitos- $\mathrm{y}$ a amenazar la hegemonía de los descendientes de los conquistadores que se jactaban de su hidalguía/fidalguia. En suma, en América, a lo largo del siglo de las luces, la riqueza se transformó en algo más poderoso que el linaje, la tradición y la memoria de la conquista.

\section{REFERENCIAS BIBLIOGRÁFICAS}

AmARAL, Luís (ed.)

2009 Livros de Matrículas dos Moradores da Casa Real; foros e ofícios 1641-1744. 2 tomos. Lisboa. Guarda-Mor.

AtienZA, Julio de

1947 Títulos nobiliarios hispanoamericanos. Madrid. Editorial Aguilar.

BAYLE, S. J. C.

1952 Los cabildos seculares en la América Española. Madrid. Sapientia.

BicalHo, Maria Fernanda

2001 "As câmaras ultramarinas e o governo do império". En Fragoso - BicAlHo - GouvÊA (orgs.), O Antigo Regime nos trópicos: a dinâmica imperial portuguesa (séc. XVIXVIII). Rio de Janeiro. Civilização Brasileira, pp.189-221.

2003 A cidade e o império. Rio de Janeiro. Civilização Brasileira.

BRADING, David

1991 Mineros y comerciantes en el México borbónico. México. F. C. E.

Büschges, Christian

1996 "Nobleza y estructura estamental entre concepto y realidad social. El caso de la ciudad de Quito y su región (1765-1810)". Jahrbuch für Geschichte von Staat, Wirtschaft und Gesellschaft Lateinamerikas. Hamburgo, no 33, pp. 165-186.

1997 "La nobleza de Quito a finales del período colonial (1765-1810). Revista Ecuatoriana de Historia. Quito, nº 10, pp. 43-61.

1999 "La formación de una nobleza colonial. Estructura e identidad de la capa social alta de ciudad de Quito (siglos XVI-XVIII)". En ScHröTER et alii, Beneméritos, aristócratas y empresarios; Identidades y estructuras sociales de las capas altas urbanas en América hispánica. Frankfurt. Vervuert, pp. 215-231.

\section{COLLECÇÃO}

1819 Chronologica de Leis Extravagantes. Coimbra. Real Imprensa da Universidade.

Domínguez OrTiz, Antonio

1973 Las clases privilegiadas en la España del Antiguo Régimen. Madrid. Istmo.

DutRA, Francis

1999 “A hard-fought for recognition". The Americas. Washington, vol. 56, pp. 91-113.

2011 "Ser mulato nos primórdios da modernidade portuguesa". Tempo. Niterói, n 30, pp. 101-114. 
Felices de la Fuente, María del Mar

2012 La nueva nobleza titulada de España y América en siglo XVIII (1701-1746). Almería. Editorial Universidad de Almería.

FraGoso, João

2001 "A formação da economia colonial no Rio de Janeiro e de sua primeira elite senhorial". En Fragoso - Bicalho - Gouvêa (orgs.), O Antigo Regime nos trópicos: a dinâmica imperial portuguesa (séc. XVI-XVIII). Rio de Janeiro. Civilização Brasileira, pp. 29-71.

2007 "Fidalgos e parentes de preto" En Fragoso et alii, Conquistadores e negociantes. Rio de Janeiro. Civilização Brasileira, pp. 33-120.

GuARDIOLA, Ivan Benedito

1591 Tratado de nobleza, y de los títulos y ditados. Madrid. Por la viuda de Alonso Gomez.

Guillén Berrendero, José Antonio

2008 Los mecanismos del honor y la nobleza en Castilla y Portugal, 1556-1621. Tesis Doctoral. Madrid. Universidad Complutense.

KICZA, John E.

1982 "The great families of Mexico: Elite maintenance and business practices in Late Colonial Mexico City". The Hispanic American Historical Review. Durham, n 63, (3), pp. 429-457.

Krause, Thiago N.

2012 Em busca da honra. São Paulo. Annablume.

LADD, Doris

1976 The Mexican nobility at Independence, 1780-1826. Austin. The University of Texas.

LANGUE, Frédérique

1992 Mines, terres et société a Zacatecas (Mexique) de la fin du XVIIIe siècle a l Indépendance. Paris. Publications de la Sorbonne.

1999 “Estrategas o patriarcas? La aristocracia empresarial zacatecana”. En SCHÖTER y Büschges (eds.), Beneméritos, aristócratas y empresarios. Frankfurt. Vervuert, pp. 275-295.

LiRa MontT, Luis

1981 "Normas sobre la concesión de títulos de Castilla a los residentes en Indias". Revista Hidalguía. Madrid, nº 166-167, pp. 629-656.

2010 La nobleza en Indias; estructura y valores sociales. Santiago. Publicaciones Bicentenario, vol. 1.

LOHMANn ViLlena, Guillermo

1993 Los americanos en las Ordenes Nobiliarias. Madrid. CSIC.

Martínez, María E.

2008 Genealogical fictions. Stanford. Stanford University Press.

Martínez BARACS, Andrea

2008 Un gobierno de indios Tlaxcala, 1519-1750. México. F. C. E.

Mello, J. A. Gonsalves de

1967 “Henrique Dias”. En Mello, J. A., Restauradores de Pernambuco. Recife. Imprensa Universitária, pp. 7-71.

Mello, Evaldo Cabral de

1986 Rubro veio. Rio de Janeiro. Nova Fronteira.

Monteiro, Nuno G.

1998 O crepúsculo dos grandes; a casa e o patrimônio da aristocracia em Portugal (1750- 
1832). Lisboa. Imprensa Nacional Casa da Moeda.

2009 “A circulação das elites no império dos Bragança”. Tempo. Niterói, n 27, pp. 65-82.

OLIVAL, Fernanda

2001 As ordens militares e o Estado moderno. Lisboa. Estar.

1998-1999 "O Brasil, as Companhias pombalinas e a nobilitação no terceiro quartel do setecentos”. Anais. Évora, ns. 8/9, pp. 73-97.

Ponce Leiva, Pilar

1996 Elite local y cabildo de Quito, siglo XVII. Tesis Doctoral, Departamento Historia de América I, Facultad de Geografía e Historia, Universidad Complutense de Madrid.

Postigo Castellanos, Elena

1998 Honor y privilegio en la Corona de Castilla. Madrid. Junta de Castilla y León.

Privilegios

1611 --- dos cidadãos da Cidade do Porto. Porto. Em Casa de Fructuoso Lourenço de Basto.

RAMINELLI, Ronald

2008 Viagens ultramarinas. São Paulo. Alameda.

2012 “Índios cavaleiros das Ordens Militares”. En Fernandes (Org.), As Ordens Militares, Freires, Guerreiros, Cavaleiros. Palmela. Câmara Municipal de Palmela, v. 2, pp. 655-677.

2013 “Classifications sociales et hiérarchies de la couleur”. Nuevo Mundo Mundos Nuevos [Online], http://nuevomundo.revues.org/64678.

2013a "Súbditos de frontera de la América portuguesa (siglos XVI y XVII)". En RuIZ IBÁÑEZ (coord.). Las vecindades de las Monarquías Ibéricas. Madrid. F. C. E., pp. 291-312.

Rizo-Patrón Boylan, Paul

2000 Linaje, dote y poder; la nobleza de Lima de 1700 a 1850. Lima. Pontificia Universidad Católica del Perú.

SAmpayo, Antonio de Villasboas

1676 Nobiliarchia Portugueza; tratado de nobreza hereditária epolítica. Lisboa. Oficina Francisco Vilella.

SchwARTZ, Stuart B.

1988 Segredos internos; engenhos e escravos na sociedade colonial. São Paulo. Companhia das Letras.

STumpF, Roberta G.

2009 Cavaleiros do ouro e outras trajetórias nobilitantes. Tese de Doutorado. Brasília. Universidade de Brasília.

Soria Mesa, Enrique

2013 "Los estatutos municipales de limpieza de sangre en la Castilla moderna. Una revisión crítica". Mediterranea, ricerche storiche. Palermo, n² 27, pp. 9-36.

VARNHAGEN, F. Adolfo de

1981 História Geral do Brasil. 3vs. Belo Horizonte, São Paulo. Itatiaia, Edusp.

VASCONCELOS, Frazão de (ed.)

1940 Henrique Dias; herói da Restauração de Pernambuco. Lisboa. Agência Geral das Colônias.

VERA, Álvaro Ferreira de

2005 Origem da nobreza politica [1631]. Lisboa. Livro Aberto. 